\title{
Outlet Port Valve Device
}

National Cancer Institute

\section{Source}

National Cancer Institute. Outlet Port Valve Device. NCI Thesaurus. Code C50253.

A valve designed to control the flow of fluids out through the wall of a chamber. 